\title{
Study on Logistics Pattern of Cross-border E-commerce
}

\author{
Yinghan Liu, a \\ ${ }^{1}$ Chongqing College of Electronic Engineering, China, 400331 \\ aliuyinghan_lynn@163.com
}

\section{Keywords: Cross-border E-commerce; Logistics; Pattern study}

\begin{abstract}
Cross-border e-commerce is an international merchandise trade which takes e-commerce platform as a carrier to close the deal and payment and draws support from international logistics to transport goods. It is the trend of social development as well as the presentation of increasing frequency of enterprise exchange around the world. In the operation and development process, the cross-border e-commerce puts forward a higher request to logistics. In addition, the logistics pattern will directly affect the benefit and sustainable development of cross-border e-commerce. This paper will mainly discuss the logistics pattern and the logistics development strategy of cross-border e-commerce so as to promote the stable development of cross-border e-commerce.

Cross-border e-commerce not only can meet the actual demand of consumer for purchasing and after-sales service but also can optimize the consuming experience of consumer. Meanwhile, the sales market of product can be expanded extremely under the cross-border e-commerce circumstances to improve the supply chain efficiency and bring more benefits to enterprise. All of these need the support of international logistics so as to guarantee the transport quality and promote the development of cross- border e-commerce. Our country must be fully aware of the significance of cross- border e-commerce to trade development and proceed from reality to adjust and reform the pattern of international logistics and promote the development and prosperity of import and export trade.
\end{abstract}

\section{Logistics Pattern of Cross-border E-commerce}

Overseas Warehouse. Overseas warehouse is a logistics pattern that the cross-border e-commerce enterprise establishes product warehouse beyond the border or rents the local warehouse to store products so as to be convenient for transport in their marketing. Under this trade pattern, enterprise will store a large number of products in the overseas warehouse and adopt online-sales mode to transfer the product from the overseas warehouse to consumer when consumer places an order. This logistics pattern can effectively reduce the time and cost of logistics, especially the time that the consumer gets the product. Moreover, it contributes to the quality inspection of goods. However, it will cause a lot of fun cost to establish or rent overseas warehouse, and bring economic burden to enterprise. It is more suitable for the enterprise with stronger economic strength.

Border Warehouse. Border warehouse is an international logistics pattern similar to overseas warehouse. Both of them are established in the location which is far from enterprise and near to consumer so as to store goods temporarily. The difference is that overseas warehouse including self-built warehouse and rented warehouse is beyond the border and the border warehouse, in the neighborhood of national boundary including self-built and rented one, in spite of a certain distance from enterprise. Meanwhile, the location of warehouse is nearer to the importing country of main products. The advantage of border warehouse is to reduce the logistics cost. In addition, enterprise can enjoy the policy support related to logistics of target country and avoid the risk of tax, politics and law etc. to some extent. Border warehouse also is an international logistics pattern with higher consumption and fund requirement at the earlier stage. It has a certain requirement for the strength of enterprise.

Goods Collection Logistics. Goods collection logistics is to collect a great many of small-batch goods to distribute. The advantage of this pattern is to improve the loading efficiency of international logistics greatly and avoid light load or empty load. Meanwhile, it also can reduce the 
cost of logistics distribution of enterprise tremendously to strengthen the distribution efficiency of product so as to save the logistics cost for enterprise. In the process of goods collection, goods collection logistics is centralized. But in the process of actual transport, the goods must be delivered to each consumer separately. This also brings a great challenge for the logistics distribution. Consequently, it is a must to establish the corresponding storage logistics center if the goods collection logistics is adopted so as to overall plan the logistics distribution of product and improve the satisfaction of consumer.

Special International Logistics Line. Special international logistics line is an international logistics line with special purpose, developed by logistics enterprises from countries around the world. The purpose is to promote the high-efficiency logistics distribution between countries. It connects two trading countries directly. In the actual confirming process, each special line under such logistics pattern is confirmed in accordance with the trade characteristics of different regions and countries. In the process of logistics transport, this pattern can avoid various risks in customs clearance of product to the greatest extent, and with a good timeliness. Moreover, it also can shorten the delivery time greatly and bring a nice consuming experience to consumer.

Bonded or Free Trade Zone Logistics. In the logistics pattern of bonded or free trade zone, it is necessary to first transport the product of enterprise to the warehouse in free trade zone or bonded zone for a temporary storage. After the agreement between cross-border e-commerce enterprise and consumer is reached, the corresponding product will be transported from free trade zone or bonded zone, which makes the logistics distribution more convenient. The advantage of this pattern is to maximize the trade advantage of free trade zone or bonded zone, strengthen the stability of international logistics transportation and guarantee the benefits of enterprise and the rights and interests of consumer.

Fourth Party Logistics. Fourth party logistics is a new concept of international logistics pattern, originating in America. In the operation of this pattern, it will play the roles of logistics planning, consultation, supply chain management and others related to international logistics rather than directly participating in the logistics activity. The main advantage and feature of this pattern is to provide a systematic and perfect solution for the supply chain of international logistics, optimize the logistics distribution of customer to the greatest extent through overall planning and comprehensive management, and select the most suitable logistics pattern to strengthen the distribution efficiency of product so as to reduce the cost of logistics and effectively improve the benefits of logistics enterprise.

\section{Logistics Development Strategy of Cross-border E-commerce}

Improve the Service Efficiency of Overseas Warehouse. The advantage of cross-border e-commerce is the large total batch and the small sub-batch, which can meet the differentiated demand of consumer for product. The overseas warehouse can further provide a nice consuming experience for consumer. Meanwhile, to improve the service efficiency of overseas warehouse also is an effective measure to break through dilemma of cross-border e-commerce logistics. The trade enterprise adopting cross-border e-commerce can store its own product into the overseas warehouse or border warehouse in batch through establishing overseas warehouse or border warehouse. Once the order is formed on e-commerce platform, the product can be delivered from overseas warehouse or border warehouse directly. This pattern can effectively shorten the response time of order and promote the improvement of logistics transportation efficiency. Meanwhile, the changing or refunding service of consumer also can be added on the cross-border e-commerce platform if the inventory in warehouse is sufficient so as to strengthen the satisfaction of consumer. This can solve the problem that consumer cannot communicate effectively with merchant in product changing or refunding while improving the quality of after-sales service, through which the rights and interests of consumer are protected really. However, the overseas warehouse patter has a higher requirement for the accuracy of market forecasting so as to avoid the excessive inventory resulted from the poor sale of product. The advantage of overseas warehouse and border warehouse is obvious. But the enterprise is required to have a sufficient economic strength. The small and medium-sized 
enterprises can effectively use the overseas warehouse of third party or establish the overseas allied warehouse through cooperation with other enterprises to reduce the logistics risk and cost.

Effectively Perfect the Cross-border Customs Clearance service. Most cross-border e-commerce logistics adopt the method of customs declaration to be cleared by the customs. This method makes the efficiency of international logistics reduced greatly since the procedure required in customs declaration is complicated relatively and requiring a long time, which will extend the time of logistics distribution greatly. National General Administration of Customs and other relevant departments must realize this problem and the current situation, and actively set up the customs clearance and service platform of e-commerce enterprise to make logistics companies to directly interconnect with customs electronic port platform and e-commerce platform for customs declaration and effectively simplify the procedure of customs declaration. Meanwhile, the support from information technology also should be taken to promote the normalized and standardized construction of cross-border e-commerce logistics. In addition, the relevant department also should strengthen the analysis and research for characteristics and rules of cross-border e-commerce logistics to enhance the quality and efficiency of customs clearance service, effectively meet the customs declaration demand of enterprise so as to further promote the international cooperation of cross-border e-commerce and the development and prosperity of import and export trade of our country.

Lay Emphasis on Cultivating the Talents in Cross-border E-commerce. Cross-border e-commerce is a completely new trade form as well as the trend of trade development. It embodies the development characteristics of modern economy, and having a great vitality. But the lagging in international logistics development of cross-border e-commerce has affected the development of cross-border e-commerce. This has restricted the progress of trade while reducing the speed of development. A large number of traditional enterprises have a certain consciousness to transform to cross-border e-commerce. But they always are lack of appropriate talents in cross-border e-commerce, which makes these enterprises cannot obtain the ideal results in the actual process of transformation. The cross-border e-commerce logistics enterprise also is lack of the e-commerce talents with high comprehensive quality to change the lagging development of cross-border e-commerce logistics. This makes to lay emphasis on cultivating the talents in cross-border e-commerce to become an effective strategy to break through the dilemma of cross-border e-commerce. In order to effectively solve this problem, the cooperation between university and enterprise can be adopted to make the cross-border e-commerce enterprise to cooperate with the corresponding major of each university so as to meet the demand of such enterprise for outstanding talents. Meanwhile, the enterprise must systematically make and implement the talents cultivating strategy conforming to enterprise development and promoting the progress of talents in cross-border e-commerce so as to cultivate more applied talents with comprehensive quality in e-commerce. In addition, the enterprise also can rally the policy and financial supports from relevant departments and educational administrative department to provide an effective guarantee for the implementation of talents cultivating plan.

Lay Emphasis on Strengthening Information Technology Application. With the development and the enlargement of scope of cross-border e-commerce, the requirement for international logistics also is improved gradually, which needs to effectively reform and innovate the logistics system of cross-border e-commerce so as to better meet the prosperity and development demand of cross-border e-commerce trade. Informatization, professionalization and standardization are the trend of development and reform of logistics system as well as the direction which must be grasped. The standardization reform of logistics service system can reduce the rate of damaged cargo and the packet loss rate, and avoid the loss for enterprise and consumer. Meanwhile, for e-commerce platform and international logistics, the perfection in connecting interface of department and the standardized construction in circulation and storage etc. of goods can enhance the quality of logistics service. The professionalization and informatization construction of logistics service system meets the requirement of era of knowledge economy, and compatible with the rapid scientific and technological development of modern society. The demand of consumer is analyzed 
intelligently and systematically mainly through constructing intelligent database so as to effectively arrange the inventory and reduce the cost of inventory. In addition, the geographical location of product also can be mastered timely and effectively to implement a full period tracking and service. The overstocking of commodities also can be avoided effectively while guaranteeing the timeliness of logistics distribution to bring a nice experience to audience and strengthen the satisfaction of consumer.

Unblock the Feedback Channel of Logistics Information. Logistics enterprise belongs to the third party. Meanwhile, it also is an independent economic individual. We can say it has established the communication bridge for the domestic cross-border seller and the overseas consumer. Logistics enterprise not only can sell the service but also can directly receive the payment and comment from consumer, and closely connect and communicate with consumer. Consequently, in addition of joint distribution mode formed between cross-border e-commerce enterprise and logistics company, a long-term and stable cooperation agreement between them can be reached in accordance with this feature to guarantee the effective feedback and communication of information. Logistics enterprise can fully make use of the convenience itself to effectively know the actual demand of consumer. In addition, in order to meet the individual need of consumer, the unimpeded information feedback channel can be specially set up to receive the comment and feedback from consumer, and transmit such feedback to cross-border e-commerce enterprise finally. This is beneficial to the realization of long-term interests and cooperation between both sides. Meanwhile, the consumer can effectively supervise the logistics service and product. The cross-border e-commerce enterprise also can grasp the information of consumer to make the connection degree of each link enhanced greatly and help the cross-border e-commerce logistics to break through the dilemma.

\section{Conclusion}

With the development of economic globalization and the speed increase of economic development, cross-border e-commerce has been developed gradually as an important trade tendency. It conducts the transaction and payment with the help of e-commerce platform effectively and uses international logistics to transport goods, which has improved the convenience of commodity circulation and brought a nice consuming experience to consumer. The logistics pattern of cross-border e-commerce is the major factor to affect its development. Therefore, it is a must to reasonably and properly select the logistics pattern, put forward the targeted strategy based on the existing problem and dilemma in development of cross-border e-commerce logistics pattern and promote the development of cross-border e-commerce through adjusting and innovating the international logistics pattern.

\section{References}

[1] X.G. Cao: Logistics Business Pattern and Innovation Approach of Cross-border E-commerce. Practice in Foreign Economic Relations and Trade, 2015, (5):93-96.

[2] J. Fan: Experience and Inspiration on Innovation of Logistics Pattern of Cross-border E-commerce. Journal of Commercial Economics, 2016, (11):133-135.

[3] B. Li: Current Situation of Cross-border E-commerce and Selection of International Logistics Pattern. Practice in Foreign Economic Relations and Trade, 2015, (4):37-39.

[4] Y. Liu: Comparison and Selection on Competitiveness of Logistics Channel of Cross-border E-commerce in Middle and Small-sized Enterprises. Journal of Jilin Business and Technology College, 2014, (4):87-89.

[5] Y. Zeng: Study on Development Problem of Cross-border E-commerce Logistics. Management \& Technology of SME, 2014, (9):130-131. 